\title{
Mycoplasma dispar prevalence in the upper respiratory tract of cattle and the antimicrobial susceptibility of the isolates
}

\author{
J. Šiugždaitè, A. Gabinaitienė \\ Lithuanian University of Health Science, Veterinary Academy, Department of Infectious Diseases, \\ Tilzes str. 18, Kaunas, LT-47181, Lithuania \\ E-mail: jurate.siugzdaite@lva.lt
}

\author{
R. Šiugžda \\ Lithuanian University of Health Science, Medical Academy, Department of General Surgery, \\ Josvainiu str. 2, Kaunas, LT-47144, Lithuania \\ E-mail: remigijussiugzda@gmail.com
}

crossref http://dx.doi.org/10.5755/j01.ct.65.1.8716

Received 8 October 2014; Accepted 11 November 2014

The aim of this study was to make a survey of the presence of Mycoplasma dispar on a cattle breeding farm and to determine antimicrobial susceptibility of the isolates.

The study was carried out at a farm in Lithuania. Nasal swabs for bacteriological investigation were collected from ninety dairy, beef and mixed type of cattle from 90 to 300 days of age. Mycoplasma cultivation procedures were carried out using Friis selective media. To confirm the presence of Mollicutes class the polymerase chain reaction (PCR) was used. Isolates were identified according to biochemical and antigenic characteristics.

The minimum inhibitory concentration of twenty field isolates of Mycoplasma dispar to tulathromycin, tylosin, lincomycin, enrofloxacin, florfenicol, and oxytetracycline was determined by using a micro-broth dilution method.

Mycoplasma dispar was detected in the nasal cavity of 15 out of 84 clinically healthy animals (17.9\%), and in 5 out of 6 animals with respiratory disorders $(83.3 \%)$. The isolates were most susceptible to tulathromycin, lincomycin, enrofloxacin and florfenicol. Three $(15 \%)$ isolates were resistant to oxytetracycline.

The susceptibility to oxytetracycline significantly differed between Mycoplasma dispar isolates compared to the susceptibility of tulathromycin $(P<0.001)$, lincomycin $(P<0.001)$ tylosin $(P<0.001)$, enrofloxacin $(P<0.001)$, and florfenicol $(P<0.001)$.

Keywords: antimicrobial agents; cattle; Mycoplasma dispar

\section{Introduction}

Cattle respiratory diseases are one of the major health problems in feedlots. The most important of these diseases is the bovine respiratory disease complex (BRDC). The clinical entity of BRDC most often manifested is bronchopneumonia. It is usually associated with the assembly of large numbers of weaned calves into a feedlot environment. BRDC has a multifactorial etiology and develops as a result of complex interactions between environmental factors, host or animal factors and pathogens [1]. The role of Mycoplasma dispar ( $M$. dispar) in BRDC is uncertain, primarily due to culturing difficulties, which means that many laboratories that test for mycoplasmas, overlook this species, leading to a considerable underestimate of the prevalence [2].

Mycoplasma dispar is a common inhabitant of the upper and lower respiratory tract of healthy cattle. Several studies has shown that Mycoplasma dispar currently was present in $50 \%$ of the examined herds, and bacterial agents of the syndrome, i. e. Pasteurella multocida, Arcanobacterium pyogenes or Mannheimia haemolytica coexisted with these cases [3]. In the development of respiratory disease in dairy calves, $M$. dispar may play an initiating role for leading to subclinical and clinical pneumonia. Dutch studies $[4,5]$ showed that $M$. dispar was present in $92 \%$ of pneumonic lungs from 148 calves and only in $40 \%$ of healthy lungs from 270 calves. In Denmark, Tegtmeier et al. [6] isolated $M$. dispar from 13 of 31 lungs showing fibrinnecrotizing bronchopneumonia, from 15 of 31 lungs with suppurate bronchopneumonia and from 3 of 31 lungs with embolic bronchopneumonia. In Canada, M. dispar was isolated from more than half of 300 pneumonic calf lungs [7].

Mycoplasma dispar appears less immunogenic in calves, and vaccine given either intramuscularly or intratracheally or both do not produce a detectable protection from colonization, which may at least partly form its pathogenicity [8].

Often the cost of respiratory disease estimated on data concerning morbidity and mortality, usually based on the clinical appearance of animals. The assumption is that clinically normal animals are not affected by the disease, and do not contribute to the economic impact of disease outbreak. However, it is shown that many animals that are exposed to respiratory pathogens will seroconvert and may be sub-clinically infected, which has a negative effect on the growth rate, fattening period and carcass 
grades. These costs are likely to be underestimated in studies of the impact of respiratory disease [9].

The role of Mycoplasma dispar as an active agent in cases of bovine respiratory disease is poorly elucidated in Lithuania. The aim of this study was to investigate the presence of Mycoplasma dispar on a breeding farm and to determine antimicrobial susceptibility of the isolates.

\section{Materials and methods}

Animals. $M$. dispar was studied in a cattle breeding farm in Lithuania from 90 bulls (30 dairy cattle, 30 beef cattle, and 30 dairy-beef cattle breeds). Male cattle were investigated according to the requirements of the Law of Republic of Lithuania on animal care, keeping and using No B1-639 ("Valstybès Žinios", 200901 22, No. 8-287). The herd included 300 male cattle. The age of the investigated cattle ranged from 90 to 300 days. The cattle were brought to the control breeding farm from various regions of Lithuania at the age of 3 months. New animals from other herds were introduced to the farm continuously. The investigated cattle were kept in barns until time of slaughter, which were at 510 days of age. The cattle were fed herb hay; silage and concentrate forage in winter. In summer the cattle were given green grass mass and concentrate forage. No vaccines and antibiotics were used as preventive measures.

A clinical assessment of each animal was performed before samples from nasal cavity were collected. General appearance and respiratory symptoms were scored on a 4 point scale [10] (Table 1). The rectal temperature of each animal was measured.

Table 1. Evaluation rates of the cattle health status and respiratory symptoms

\begin{tabular}{|c|l|l|l|l|}
\hline $\begin{array}{c}4 \\
\text { point } \\
\text { scale }\end{array}$ & $\begin{array}{c}\text { General } \\
\text { appearance }\end{array}$ & $\begin{array}{l}\text { Respiratory } \\
\text { signs }\end{array}$ & $\begin{array}{c}\text { Nasal } \\
\text { discharge }\end{array}$ & Coughing \\
\hline 0 & normal & absent & absent & absent \\
\hline 1 & $\begin{array}{l}\text { subdued, } \\
\text { slightly } \\
\text { depressed }\end{array}$ & $\begin{array}{l}\text { hyperpnoea } \\
\text { or slight } \\
\text { dyspnea }\end{array}$ & $\begin{array}{l}\text { mild } \\
\text { secretion }\end{array}$ & mild \\
\hline 2 & $\begin{array}{l}\text { depressed, } \\
\text { reluctant to } \\
\text { rise }\end{array}$ & $\begin{array}{l}\text { moderate } \\
\text { hyperpnoea } \\
\text { or obvious } \\
\text { dyspnea }\end{array}$ & $\begin{array}{l}\text { catarrhal } \\
\text { secretion }\end{array}$ & rare \\
\hline 3 & $\begin{array}{l}\text { very } \\
\text { depressed, } \\
\text { unresponsive } \\
\text { to external } \\
\text { stimuli }\end{array}$ & $\begin{array}{l}\text { respiratory } \\
\text { distress }\end{array}$ & $\begin{array}{l}\text { suppurative } \\
\text { secretion }\end{array}$ & $\begin{array}{l}\text { Frequent } \\
\text { in oneral } \\
\text { minute }\end{array}$ \\
\hline
\end{tabular}

Isolation and identification of Mycoplasma dispar. Twenty $M$. dispar isolates were obtained by the Microbiology Laboratory of Department of Infectious Diseases in the Veterinary Academy of Lithuanian University of Health Sciences.

The bacteriological examination of samples from nasal cavities of cattle for Mycoplasma dispar species was carried out using Friis selective media [11]. The nasal swabs were placed in the Friis NHS-20 broth by making dilutions from $10^{-1}$ to $10^{-4}$ and were incubated in microaerophilic conditions for 3-4 days. After the colour of the broth culture changed indicating mycoplasma growth, broth was inoculated on to Friis NHS-20 agar plates. The solid media were incubated in microaerophillic conditions for 14-21 days [11]. The cultures of $M$. dispar were purified three times by conventional filtration cloning techniques with a $450 \mathrm{~nm}$ pore size membrane filter [12].

A polymerase chain reaction (PCR) was used for the identification of the Mollicutes class [13].

DNA from isolated mycoplasma was extracted with $5 \%$ solution of Chelex (Sigma, USA). Isolated microorganisms were analyzed by PCR using forward primer, MW28 (5'- CCAGACTCCTACGGGAGGCA $3^{\prime}$ ) and reverse oligonucleotide primer MW29 (5'- T GCGAGCATACTACTCAGGC - $3^{\circ}$ ) (Grida Lab, Lithuania) that are specific for the Mollicutes class [13]. This pair of primer generates a 560 bp product.

For the identification of $M$. dispar species, isolates were tested for biochemical properties: glucose fermentation, arginine hydrolysis, phosphatase activity, tetrazolium reduction and production of spots and films [14]. To determine Mycoplasma dispar discs growth inhibition (DGI) test was used [15]. All isolates were stored in NHS-20 broth at $-70{ }^{\circ} \mathrm{C}(\mathrm{N}$-medium - $320 \mathrm{ml}$, horse serum - $40 \mathrm{ml}$, swine serum - $40 \mathrm{ml}$, cycloserine $60 \mathrm{mg})$.

Antimicrobial agents. Antimicrobials tested in this study were tulathromycin (Pfizer, United States), tylosin (Chemifarma, Italy), lincomycin (Pfizer, United States), enrofloxacin (Vetoquinol, Austria), florfenicol (KRKA, Slovenia) and oxytetracycline (Chemifarma, Italy). Serial twofold dilution of drugs was performed in test tubes with NHS-20 broth. Final concentrations of $100 \mu \mathrm{g} / \mathrm{ml}$ for tylosin, lincomycin, enrofloxacin, florfenicol, oxytetracycline and $32 \mu \mathrm{g} / \mathrm{ml}$ for tulathromycin were prepared with some modifications as described by Hannan [16]. Tylosin, oxytetracycline and enrofloxacin were obtained in pure form. Tylosin and oxytetracycline were first dissolved in $10 \%$ methanol, enrofloxacin in 2 $\%$ potassium hydroxide, and then the solution was completed to final volume using distilled water. Liquid form of lincomycin, florfenicol and tulathromycin were diluted in distilled water to prepare stock solutions. The stock solutions were sterilized by filtering through a 200 $\mathrm{nm}$ pore size membrane filter and used immediately.

Micro-broth dilution test. Minimal inhibitory concentration (MIC) of each antimicrobial agent was determined by applying micro-broth dilution test according to the recommendations of Hannan [16] and Ter Laak et al. [17]. Each antimicrobial agent was serially diluted into twofold dilution in Friis NHS-20 broth (containing no selective supplements) from the highest concentration $(100 \mu \mathrm{g} / \mathrm{ml}$ and $32 \mu \mathrm{g} / \mathrm{ml})$ in wells of micro titer plates; each well containing $100 \mu$ l. The last columns of micro titer plates were filled with $100 \mu \mathrm{l}$ of broth medium without antimicrobials (growth control). One hundred micro liters' of mycoplasma inoculums $\left(10^{4}\right.$ $10^{5} \mathrm{ccu} / \mathrm{ml}$ of each strain freshly cultured for $2 \mathrm{~h}$ at $37^{\circ} \mathrm{C}$ ) were added to columns. Plates were sealed and incubated 
aerobically at $37{ }^{\circ} \mathrm{C}$ for 3 to 4 days. The susceptibility of $M$. dispar isolates to an antimicrobial agent was indicated by a growth-induced $\mathrm{pH}$ shift in the medium. MIC for each isolate and each antimicrobial was defined as the lowest concentration of antimicrobials to completely inhibit visible growth ( $\mathrm{pH}$ change) in the broth. $\mathrm{MIC}_{50}$ and $\mathrm{MIC}_{90}$ values were defined as the lowest concentrations capable of inhibiting the growth of $50 \%$ and $90 \%$ of isolates, respectively [16-18].

The number of mycoplasmas for inoculum in MICs test was determined by micro-broth dilution method described by Hannan [16]. Broth culture of each isolate was diluted to tenfold dilution in Friis NHS-20 broth and dispensed in to microtiter plates. The plates were sealed and incubated aerobically at $37{ }^{\circ} \mathrm{C}$. The lowest dilution showed a change of color of the broth medium from red to yellow was determined as the number of color changing units (ccu) of mycoplasma culture.

To ensure micro-broth dilution test reproducibility and validity, strain $462 / 2$ of $M$. dispar was used as a reference. MIC test was repeated three times.

Interpretation of MIC results. Since there are no accepted breakpoints for the $M$. dispar susceptibilities determination, criteria described by Hannan [16] were used for interpretation of MIC results. Values are shown in Table 2.

Table 2. MIC breakpoints against mycoplasma species

\begin{tabular}{|l|c|c|c|c|c|}
\hline \multirow{2}{*}{} & \multicolumn{5}{|c|}{ Antimicrobial material groups } \\
\cline { 2 - 6 } & Tetracyclines & Lincosamides & Quinolones & Amphenicols & Macrolides \\
\hline Sensitive & $\leq 4 \mu \mathrm{g} / \mathrm{ml}$ & $\leq 2 \mu \mathrm{g} / \mathrm{ml}$ & $\leq 0.5 \mu \mathrm{g} / \mathrm{ml}$ & $\leq 4 \mu \mathrm{g} / \mathrm{ml}$ & $\leq 1 \mu \mathrm{g} / \mathrm{ml}$ \\
\hline Intermediate & $\leq 8 \mu \mathrm{g} / \mathrm{ml}$ & $\leq 8 \mu \mathrm{g} / \mathrm{ml}$ & $\leq 1 \mu \mathrm{g} / \mathrm{ml}$ & $\leq 8 \mu \mathrm{g} / \mathrm{ml}$ & $\leq 2 \mu \mathrm{g} / \mathrm{ml}$ \\
\hline Resistant & $>8 \mu \mathrm{g} / \mathrm{ml}$ & $>8 \mu \mathrm{g} / \mathrm{ml}$ & $\geq 2 \mu \mathrm{g} / \mathrm{ml}$ & $\geq 16 \mu \mathrm{g} / \mathrm{ml}$ & $\geq 4 \mu \mathrm{g} / \mathrm{ml}$ \\
\hline
\end{tabular}

Statistical analysis. Descriptive statistical analyses were performed with SPSS 13.0 Windows statistical packet (2004). Kruskal-Wallis test was used to examine the equality between the isolates medians for each MIC value. $P<0.05$ was considered as significant.

\section{Results and discussion}

Six $(6.7 \%)$ cattle of the investigated group had respiratory system disorders: animals were slightly depressed; there were abnormal sounds on auscultation of the respiratory tract, some of them suffered from cough or nasal discharge. The rectal temperature of these cattle was $>39.5{ }^{\circ} \mathrm{C}$. No respiratory system disorders were noticed in $84(93.3 \%)$ of the investigated cattle - these cattle were clinically healthy.

The bacteriological examination of samples from the nasal cavity of 90 investigated cattle identified Mycoplasma dispar in twenty (22.2\%) samples. PCR confirmed that all (100\%) M. dispar isolates belong to Mollicutes class. Fifteen (17.9\%) clinically healthy and five $(83.3 \%)$ cattle with respiratory system disorders shed Mycoplasma dispar in their nasal cavity.

The antimicrobial susceptibility test to six different antimicrobial agents revealed that all (100\%) M. dispar isolated from clinically healthy cattle was susceptible to tulathromycin. The range of MICs for tulathromycin was 0.06 to $0.5 \mu \mathrm{g} / \mathrm{ml}$. All $(100 \%)$ isolates of $M$. dispar were susceptible to tylosin. The range of MICs for tylosin was $0.39-1.56 \mu \mathrm{g} / \mathrm{ml}$. According to the breakpoints of MICs to quinolone, $100 \%$ of the isolates were susceptible to enrofloxacin. The range of MIC for enrofloxacin was $0.39-0.78 \mu \mathrm{g} / \mathrm{ml}$. All (100\%) isolates of M. dispar from cattle of different ages were susceptible to florfenicol and lincomycin. The range of MICs for florfenicol and lincomycin were $0.39-3.12 \mu \mathrm{g} / \mathrm{ml}$ and $0.39-0.78 \mu \mathrm{g} / \mathrm{ml}$, respectively.
In the present study, 17 (85\%) isolates of M. dispar were found to be sensitive to oxytetracycline. Three $(15 \%)$ isolates were resistant to oxytetracycline. The range of MICs for oxytetracycline was from 1.56 to $25 \mu \mathrm{g} / \mathrm{ml}$.

All $(100 \%)$ the isolates of $M$. dispar isolated from cattle with respiratory disease were susceptible to tulathromycin, tylosin, enrofloxacin, florfenicol, and lincomycin. There were two types of isolates with respect to their susceptibility to oxytetracycline. Three $(60 \%)$ of five isolates were susceptible to oxytetracycline, two (40\%) - were resistant.

The statistical data analysis revealed that MIC results obtained during the study did not contradict each other $(P<0.001)$. MIC data were evaluated applying SPSS 13.0 statistical package, and it was determined that $M$. dispar isolates had a similar susceptibility pattern with respect to tulathromycin, enrofloxacin, florfenicol, and lincomycin. Statistically significant differences of susceptibility of $M$. dispar to florfenicol compared with tulathromycin $(P<0.001)$, tylosin $(P<0.001)$, lincomycin $(P<0.001)$, and enrofloxacin $(P<0.001)$ were found. Susceptibility of $M$. dispar isolates to oxytetracycline significantly differed compared to tulathromycin $(P<0.001)$, lincomycin $(P<0.001)$, tylosin $(P<0.001)$, enrofloxacin $(P<0.001)$, and florfenicol $(P<0.001)$.

Mycoplasma dispar is occasionally isolated from the respiratory tract of diseased cattle, and in most reports it has been isolated in mixed infections with other known pathogens [3]. Frequently, these organisms are related with chronic or subclinical respiratory disease in cattle [19]. Several studies revealed that $M$. dispar was found in upper respiratory tract of healthy animals [4, 20].

The cattle breeding farm involved in this study houses calves brought from different regions of the country. Healthy cattle may be infected by carriers of mycoplasmas during direct contact or by aerosols. Stress 
experienced by changes in food, temperature, humidity, and ventilation and by mixing of animals from different sources is risk factors that maintain stationary mycoplasma infection. Our bacteriological studies of samples from nasal cavities showed that $M$. dispar was isolated from $17.6 \%$ of clinically healthy cattle and from $83.3 \%$ of cattle with respiratory disease symptoms. In a Dutch study, $M$. dispar was detected in $40 \%$ of clinically healthy calves [5]. Marques et al. [20] found $M$. dispar in the nasal cavity of $6.16 \%$ of healthy calves and in $34.84 \%$ of animals with respiratory disease. Clinically healthy calves may serve as a reservoir for Mycoplasma dispar, because they harbor $M$. dispar in the nasal cavity and shed the microorganism through their nasal discharge $[4,20]$. Our bacteriological studies revealed that a majority of respiratory symptoms in calves may be caused by $M$. dispar. These findings are confirmed by the study of calves in England, where $M$. dispar was isolated from the nasal cavity of $93 \%$ of healthy calves. Further studies on animals from the same source have indicated that many of these calves suffer from subclinical pneumonia, and M. dispar was isolated from the lungs of $97 \%$ of the animals [19]. It is necessary to take mycoplasmas in to consideration when examining for the microbiological cause of respiratory infection in cattle.

This is the first report on the in vitro susceptibility of $M$. dispar against six different antimicrobial agents in Lithuania. Since there are no universally accepted standards to determine antimicrobial susceptibility of mycoplasma, we have chosen the micro-broth dilution method. The inhibition of $M$. dispar growth by antibiotics was established by the organism's inability to ferment glucose and thus produce a colour change of the phenol red indicator in the medium from red to orange-yellow.

Macrolides are classified according to the number of carbon atoms which comprise the lactone ring, reaching from 12 to 16 members. It has been suggested that the 14 membered macrolides (erythromycin) were very effective against human mycoplasmal pneumonia caused by $M$. pneumonia [21]. However, in the past decade, in vitro susceptibility studies on mycoplasma have shown an increased resistance to the erythromycin [18, 22, 23]. Several studies have shown that a mixture of a 13 and 15membered ring macrolide (tulathromycin) and 16membered macrolides (tylosin) are known to be more effective against mycoplasma than the 14-membered macrolides $[23,24]$. We found that isolates of $M$. dispar isolated from clinically healthy and cattle with respiratory system disorders were sensitive to tulathromycin and tylosin. The MICs of tylosin for $M$. dispar isolates in the present study was higher $(0.39-1.56 \mu \mathrm{g} / \mathrm{ml})$ than the MICs of tylosin reported by Ter Laak et al. [17] (0.03$0.25 \mu \mathrm{g} / \mathrm{ml}$ ). In both cases the MIC values of $M$. dispar to tylosin was lower than the breakpoint of the MIC value for macrolides $(\leq 1 \mu \mathrm{g} / \mathrm{ml})$. However, tylosin has been used for many years to control bacterial diseases in Lithuanian cattle farms, and despite this, tylosin still has good in vitro activity against isolates of $M$. dispar. High susceptibility of $M$. dispar isolates to tulathromycin makes it an attractive drug for treating mycoplasma infections in the field. Furthermore, in vivo investigations of tulathromycin have demonstrated a broad spectrum of efficiency in the therapy of bovine respiratory disease [13].

Lincomycin and enrofloxacin had a similar effect against isolates of $M$. dispar. All isolates were susceptible to both agents. The MICs for lincomycin and enrofloxacin ranged from 0.39 to $0.78 \mu \mathrm{g} / \mathrm{ml}$. Ter Laak et al. [17] reported a similar effect of lincosamides and quinolones against isolates of $M$. dispar. The MIC values of $M$. dispar to lincomycin were $0.5-1 \mu \mathrm{g} / \mathrm{ml}$ and to enrofloxacin $-0.25-0.5 \mu \mathrm{g} / \mathrm{ml}$.

In the present study MICs values of isolates of M. dispar to amphenicols were lower than the breakpoint (4, 8 and $16 \mu \mathrm{g} / \mathrm{ml}$ ). All isolates were susceptible to florfenicol. This is in accordance with Ter Laak et al. [17] who reported MIC values of 2-4 $\mu \mathrm{g} / \mathrm{ml}$ to amphenicols.

Fifteen per cent of $M$. dispar isolated from clinically healthy cattle and forty per cent isolates from cattle with respiratory disease were resistant to oxytetracycline in our study. The remaining isolates were susceptible to this antimicrobial agent. Ter Laak et al. [17] also isolated oxytetracycline-resistant isolates from bovines. In the present study, the MIC values of oxytetracycline for all M. dispar field isolates were lower (1.56 to $25 \mu \mathrm{g} / \mathrm{ml}$ ) than the MICs to oxytetracycline reported by Ter Laak et al. [17]. In the past decade, in vitro susceptibility investigations of bovine mycoplasma have shown an increasing resistance to the antimicrobials of the tetracycline group [25]. Supposedly, high mutation rates of mycoplasma can rapidly develop resistance to antimicrobials as a result of gene mutation, or acquisition of new genetic material [26].

We believe that oxytetracycline-resistant $M$. dispar isolates could have accumulated mutations in genes through a wide use of tetracycline and oxytetracycline to control cattle respiratory disease and E. coli infections in calves.

\section{Conclusion}

In the present study, Mycoplasma dispar was isolated from the nasal cavity of $17.9 \%$ of clinically healthy and $83.3 \%$ of cattle with respiratory disease. The isolates were susceptible to tulathromycin, lincomycin, enrofloxacin and florfenicol, while $15.0 \%$ of the isolates were resistant to oxytetracycline.

\section{References}

1. Taylor J. D., Fulton R. W., Lehenbauer T. W., Step D. L., Confer A. W. The epidemiology of bovine respiratory disease: What is the evidence for predisposing factors // Can Vet J. 2010. Vol. 51. P. 1095-1102.

2. Miles K., McAuliffe L., Ayling R. D., Nicholas R. Rapid detection of Mycoplasma dispar and M. bovirhinis using allele specific polymerase chain reaction protocols // FEMS Microbiol Lett. 2004. Vol. 241. P. 103-107. http://dx.doi.org/10.1016/j.femsle.2004.10.010

3. Bednarek D., Szymańska-Czerwińska M., Dudek K. Bovine respiratory syndrome (BRD) etiopathogenesis, diagnosis and control, A Bird's-Eye view of veterinary medicine / Carlos C. Perez-Marin (Ed.). ISBN: 978-95351-0031-7. In Tech 2012. 
http://www.intechopen.com/books/a-bird-s-eye-view-ofveterinary-medicine/bovine-respiratory-syndrome/ $(26$ Sept. 2013)

4. Ter Laak E. A., Noordergraaf J. H., Dieltjes R. P. Prevalance of mycoplasmas in the respiratory tract of pneumonic calves // J Vet Med B. 1992. Vol. 39. P. 553562. http://dx.doi.org/10.1111/j.1439-0450.1992.tb01205.x

5. Ter Laak E. A., Noordergraaf J. H., Boomsluiter E. The nasal mycoplasmal flora of healthy calves and cows // J Vet Med A. 1992. Vol. 39. P. 610-616 http://dx.doi.org/10.1111/j.1439-0450.1992.tb01212.x

6. Tegtmeir C., Uttenthal A, Friis N. F., Jensen N. E., Jensen H. E. Pathological and microbiological studies on pneumonic lungs from Danish calves // J Vet Med B. 1999. Vol. 46. P. 693-700. http://dx.doi.org/10.1046/j.1439-0450.1999.00301.x

7. Van Donkersgoed J., Ribble C. S., Boyer L. G., Townsend H. G. Epidemiological study of enzootic pneumonia in dairy calves in Saskatchewan // Can J Vet Res. 1993. Vol. 57. P. 247-254.

8. Barrett D. C. The calf pneumonia complex - treatment decisions // Cattle Practice 8. International Conference of British Cattle veterinary association, Spring meeting, London, 2000. P. 135-138.

9. Holland B. P., Burciaga-Robles L. O., Van Overbeke D. L. et al. Effect of bovine respiratory disease during preconditioning on subsequent feedlot performance, carcass characteristics, and beef attributes // J Anim Sci. 2010. Vol. 88. P. 2486-2499.

http://dx.doi.org/10.2527/jas.2009-2428

10. Gabinaitienė A., Šiugždaitė J., Žilinskas H., Šiugžda R., Petkevičius S. Mycoplasma bovis and bacterial pathogens in the bovine respiratory tract // Vet Med Czech. 2011. Vol. 56. P. 28-34.

11. Friis N. F. Some recommendations concerning primary isolations of Mycoplasma suipneumoniae and Mycoplasma flocculare // Nord Vet Med. 1975. Vol. 27. P. 337-339.

12. Tully J. G. Cloning and filtration techniques for mycoplasmas. In: Razin S, Tully JG, eds Methods in mycoplasmology. New York, Academic Press, 1983. P. 173-177. http://dx.doi.org/10.1016/B978-0-12-583801-6.50034-2

13. Šiugždaitė J., Gabinaitienè A., Kerzienė S. Susceptibility of Mycoplasma bovis field isolates to antimicrobial agents // Vet Med Czech. 2012. Vol. 57. P. 575-582.

14. Aluotto B. B., Wittler R. G., Williams C. O., Faber J. E. Standardized bacteriologic techniques for the characterization of mycoplasma species // Int J Syst Bacteriol. 1970. Vol. 20. P. 35-58. http://dx.doi.org/10.1099/00207713-20-1-35

15. Gabinaitienè A., Šiugždaitè J., Žilinskas H. Laboratory diagnosis of mycoplasma infection in young cattle // Pol J Vet Sci. 2011. Vol. 14. P. 87-93. http://dx.doi.org/10.2478/v10181-011-0013-z

16. Hannan P.C. Guidelines and recommendations for antimicrobial minimum inhibitory concentration (MIC) testing against veterinary mycoplasma species // International Research Programme on Comparative Mycoplasmology. Vet Res. 2000. Vol. 31. P. 373-395.

17. Ter Laak E. A., Noordergraaf J. H., Verschure M. H. Susceptibilities of Mycoplasma bovis, Mycoplasma dispar and Ureaplasma diversum strains to antimicrobial agents in vitro // Antimicrob Ag Chemother. 1993. Vol. 37. P. 317-321.

http://dx.doi.org/10.1128/AAC.37.2.317
18. Gerchman I., LevisohnI S., Mikula I., Lysnyansky I. In vitro antimicrobial susceptibility of Mycoplasma bovis isolated in Israel from local and imported cattle // Vet Microbiol. 2009. Vol. 137. P. 268-275.

http://dx.doi.org/10.1016/j.vetmic.2009.01.028

19. Howard C. J. Mycoplasmas and bovine respiratory disease: Studies related to pathogenicity and the immune response-a selective review // Yale J Biol Med. 1983. Vol. 56. P. 789-797.

20. Marques L. M., Buzinhani M., Yamaguti M. et al. Use of a polymerase chain reaction for detection of Mycoplasma dispar in the nasal mucus of calves // J Vet Diag Invest. 2007. Vol. 19. P. 103-106. http://dx.doi.org/10.1177/104063870701900118

21. Yao J., Moellering R. Antibacterial agents. In: Murray P., Baron E., Jorgensen J., Landry A., Pfaller M., eds Manual of Clinical Microbiology. Washington, ASM Press, 2007. P. 1077-1113

22. Bébéar C., Pereyre S., Peuchant O. Mycoplasma pneumoniae: susceptibility and resistance to antibiotics // Future Microbiol. 2011. Vol. 6. P. 423-431. http://dx.doi.org/10.2217/fmb.11.18

23. Gharaibeh S., Al-Rashdan M. Change in antimicrobial susceptibility of Mycoplasma gallisepticum field isolates // Vet Microbiol. 2011. Vol. 150. P. 379-383. http://dx.doi.org/10.1016/j.vetmic.2011.02.005

24. Kilgore W. R., Spensley M. S., Sun F., Nutsch R. G., Rooney K. A., Skogerboe T. L. Therapeutic efficacy of tulathromycin, a novel triamide antimicrobial, against bovine respiratory disease in feeder calves // Vet Therapeut. 2005. Vol. 6. P. 143-153.

25. Thomas A., Nicholas C., Dizier I., Mainil J., Linden A. Antibiotic susceptibilities of recent isolates of Mycoplasma bovis in Belgium // Vet Record. 2003. Vol. 153. P. 428-431. http://dx.doi.org/10.1136/vr.153.14.428

26. Kibeida O. A. I. A comparison of methods used to measure the in vitro antimicrobial susceptibilities of mycoplasma species of animal origin (Doctoral Thesis) University of Pretoria, Department of Veterinary Tropical Diseases, Faculty of Veterinary Science, 2010. 98 p. 
J. Šiugždaite, A. Gabinaitienè, R. Šiugžda

MYCOPLASMA DISPAR PAPLITIMAS GALVIJU

VIRŠUTINIUOSE KVĖPAVIMO TAKUOSE IR ANTIMIKROBINIS ATSPARUMAS IŠSKIRTOMS PADERMĖMS

\section{S a n t r a u k a}

Tyrimo tikslas - nustatyti galvijus Mycoplasma dispar nešiotojus ir ištirti išskirtų mikoplazmų padermių jautrumą antimikrobinèms medžiagoms.

Mèginiai bakteriologiniams tyrimams buvo surinkti iš 90 pieninio, mèsinio ir mišraus tipo galvijų nosies ertmès, kuriu amžius buvo nuo 90 iki 300 dienų. Mikoplazmoms išskirti iš tiriamosios medžiagos naudota Friis selektyvi terpè. Mollicutes klasei nustatyti panaudota polimerazès grandininè reakcija (PGR). Mikoplazmų padermès iki rūšies nustatytos tiriant ju biochemines ir antigenines savybes. Minimali antimikrobinès medžiagos slopinimo koncentracija (MSK) nustatyta taikant serijinị paskiedimų metodą.

Ištyrus 84 kliniškai sveikus galvijus, Mycoplasma dispar buvo išskirti iš $15(17,9 \%)$ galvijų nosies ertmès. Iš 6 respiratorinėmis ligomis sergančiu galvijų $5(83,3 \%)$ buvo Mycoplasma dispar nešiotojai. Mažiausios antimikrobinių medžiagu koncentracijos, slopinančios Mycoplasma dispar padermių augimą, buvo tulatromicino, linkomicino, enrofloksacino ir florfenikolio.

Nustatėme, kad Mycoplasma dispar padermių jautrumas oksitetraciklinui statistiškai reikšmingai skyrèsi nuo šiu padermiu jautrumo tulatromicinui $(P<0,001)$, lincomicinui $(P<0,001)$, tilozinui $(P<0,001)$, enrofloksacinui $(P<0,001)$ ir florfenicolui $(P<0,001)$.

Reikšminiai žodžiai: antimikrobinès medžiagos, galvijai, Mycoplasma dispar. 